\title{
Comparison of two different methods for the determination of erythrocyte sedimentation rate
}

\author{
Eritrosit çökme hızının belirlenmesi için farklı iki yöntemin karşılaştırılması
}

Gülfer Öztürk ${ }^{1}$, Şeyda Özdemir ${ }^{1}$, Aynur Altuntaş $^{2}$, Sümeyya Akyol ${ }^{3}$, Erdem Bulut ${ }^{1}$, Gönül Erden ${ }^{1}$, İsmail Temel ${ }^{1}$

\begin{abstract}
Objective: Erythrocyte Sedimentation Rate (ESR) can be used for the follow-up of number of diseases. In recent years, closed automated systems that measure ESR directly from a capped EDTA and citrate blood sample tube have been developed. In this study, we aimed to compare and evaluate the consistence of assay results of iSed Alcor Auto-instrument and Berkhun SDM60 Auto-instrument.
\end{abstract}

Methods: K2EDTA and citrated blood samples were taken from 149 randomly selected outpatients. The ESR of blood samples in tubes containing K2EDTA was determined by iSed Alcor Auto-instrument whereas Berkhun SDM60 Autoinstrument was used to determine the ESR of blood samples in tubes containing citrate.

Results: The mean \pm SD ESR was $24.48 \pm 23.10 \mathrm{~mm} / \mathrm{hr}$ (95\% Cl for the mean was 20.54-28.02 $\mathrm{mm} / \mathrm{hr}$ ) for iSed Alcor Auto-instrument and $23.94 \pm 17.24 \mathrm{~mm} / \mathrm{hr}(95 \% \mathrm{Cl}$ for the mean was $21.15-26.73 \mathrm{~mm} / \mathrm{hr}$ ) for the Berkhun Auto-instrument. We found the mean difference between two methods as $0.336 \mathrm{~mm} / \mathrm{hr}(95 \% \mathrm{Cl}$ for the mean was -2.06 to $1.39 \mathrm{~mm} /$ hr; $\mathrm{P}=0.701)$. The obtained correlation coefficient was 0.90 $(P=0.0001)$. There was no evidence of systemic bias, equal to $0.3 \mathrm{~mm} / \mathrm{hr}$ (limits of agreement, -20.6 to $21.2 \mathrm{~mm} / \mathrm{hr}$ ).

Conclusion: iSed Alcor Auto-instrument and Berkhun SDM60 Auto-instrument might be used as alternative systems each other. However, it should be monitored carefully in especially high ESR ( $>50 \mathrm{~mm} / \mathrm{hr}$ ) results and the results should be checked according to the Westergren method. $J$ Clin Exp Invest 2014; 5 (3): 371-375

Key words: Erythrocyte sedimentation rate, EDTA tube, citrate tube, Bland-Altman analyses

\section{INTRODUCTION}

Erythrocyte sedimentation rate (ESR) is a widely used, simple, cost-efficient laboratory test which has low sensitivity and high specificity $[1,2]$. ESR is

\section{ÖZET}

Amaç: Eritrosit Sedimentasyon Hızı (ESR) birçok hastalığın takip edilmesinde kullanılabilir. Son yıllarda ESR'yi direk olarak ağzı kapalı EDTA ve sitrat kan örneği tüplerinden ölçen kapalı otomatik sistemler geliştirilmiştir. Bu çalışmada iSed Alcor Oto-Cihazı ve Berkhun SDM60 Oto-CihazIarıın sonuçlarını karşılaştırmayı ve aralarındaki uyumu değerlendirmeyi amaçladık.

Yöntemler: K2EDTA ile sitratı kan örnekleri 149 adet rastgele seçilen günübirlik hastadan alındı. K2EDTA'lı tüplere alınan kan örneklerinin ESR'si iSed Alcor Auto-instrument ile tayin edilirken, sitrat içeren tüplere alınan kandan Berkhun SDM60 Auto-instrument ile tespit edildi.

Bulgular: iSed Alcor Oto-cihazı için ortalama \pm SD ESR $24,48 \pm 23,10 \mathrm{~mm} / \mathrm{saat}(20.54-28.02 \mathrm{~mm} / \mathrm{saat}$ ortalama için \%95 GA) iken bu değer Berkhun Oto-cihazı için 23,94 $\pm 17,24 \mathrm{~mm} / \mathrm{saat}(21,15-26,73 \mathrm{~mm} / \mathrm{saat}$ ortalama için \%95 GA) idi. İki yöntem arasındaki ortalama farkı $0,336 \mathrm{~mm} /$ saat $(-2,06$ ila $1,39 \mathrm{~mm} / \mathrm{saat}$ ortalama için $\% 95 \mathrm{GA} ; \mathrm{P}=$ $0,701)$. Elde edilen korelasyon katsayısı $0,90(P=0,0001)$ idi. Sistematik tarafııığa yönelik bir kanıt mevcut olmayıp $0,3 \mathrm{~mm} / \mathrm{saat}$ değerine eşitti (uyum sınırları -20,6 ila 21,2 $\mathrm{mm} / \mathrm{saat}$ ).

Sonuç: iSed Alcor Oto-cihazı ile Berkhun SDM60 Oto-cihazı birbirlerine karşı alternatif sistemler olarak kullanılabilir. Ancak özellikle yüksek ESR (>50 mm/hr) sonuçlarında dikkatli bir şekilde takip edilmeli ve sonuçlar ise Westergren yöntemine göre kontrol edilmelidir.

Anahtar kelimeler: Eritrosit sedimentasyon hızı, EDTAlı tüp, sitratı tüp, Bland-Altman analizi

used for diagnosis and follow-up of many diseases, particularly infections and inflammatory diseases. Literature reports that ESR can be used as a longterm independent predictor of coronary artery disease $[1,3]$. It has also been suggested that some

\footnotetext{
${ }^{1}$ Dışkapı Yıldırım Beyazıt Education and Research Hospital, Department of Biochemistry, Ankara, Turkey

${ }^{2}$ Ankara Branch of Council of Forensic Medicine, Division of Chemistry, Ankara, Turkey

${ }^{3}$ Turgut Özal University, Vocational School of Health Sciences, Division of Medical Laboratory Equipments, Ankara, Turkey
}

Correspondence: Şeyda Özdemir,

Dışkapı Yıldırım Beyazıt Education /Research Hospital, Dept. Biochemistry, Ankara, Turkey Email: seydasahingoz@yahoo.com 
non-specific laboratory parameters such as high levels of ESR might support the results of specific brucellosis tests [4]. ESR increases with age. An ESR value up to $15 \mathrm{~mm} / \mathrm{h}$ in males and up to 20 $\mathrm{mm} / \mathrm{h}$ in females is considered normal. The formula of age/2 in males and $+10 / 2$ in females evaluates the ESR based on the age is accepted in general [5-7].

ESR is based on in vitro sedimentation of erythrocytes. Since most plasma proteins are positively charged, they reduce their drop rate in the plasma by increasing the formation of aggregation and roll and reducing the impulse of erythrocytes [8]. Cholesterol is one of important factors that inhibit the ESR as it alters electrostatic load of erythrocytes [8].

There are many methods to measure ESR. Westergren, one of oldest methods, is currently the most useful method to measure ESR $[9,10]$. During measurement, technical factors result in variation in ESR values, such as high citrate in the tube; usage of heparin instead of citrate; holding the tube straight; changes in the room temperature; inadequate shaking of blood; and keeping the blood for a long period of time [11]. However, Westergren method is not very practical in routine analysis because of a longer period required for the results and a higher volume of blood needed [8]. Thus, a method and instrument that can measure in shorter time and lower volume of blood is still under investigation. Some methods that are used to measure ESR in routine need citrated tubes, while the others need tubes with EDTA $[1,8,12]$. StaRRsed (InteRRliner, Mechatronics, Zwaag, the Netherlands) and SEDIsystem (Becton Dickinson, Leiden, the Netherlands) utilize the citrated tubes whereas Ves-Matic Cube 200 (Diesse Diagnostica Senese, Siena, Italy) and Test 1 system (Alifax, Padova, Italy) utilize tubes with EDTA $[8,13,14]$. The other two of these systems are iSed Alcor and Berkhun SDM60. iSed Alcor uses tubes with EDTA and Berkhun SDM60 uses citrated tubes.

In this study, we aimed to compare and evaluate the consistence of assay results of iSed Alcor Auto-instrument and Berkhun SDM60 Auto-instrument.

\section{METHODS}

This study included randomly selected 149 patients who admitted to Dışkapı Yıldııım Beyazıt Training and Research Hospital. Patient blood was collected both in the K2EDTA (Becton Dickinson System,
Europe, Meylan Cedex-France) tubes and the citrated tubes (Berkhun, Çanakkale, Turkey). The ESR of blood samples in both tubes was measured within 4 hours in accordance with recommendation of International Council for Standardization in Haematology (ICSH). The ESR of blood samples in the K2EDTA tubes was determined by iSed Alcor Auto-instrument whereas the ESR of blood samples in the citrated tubes was measured by Berkhun SDM60 Auto-instrument. The ESR results are presented in $\mathrm{mm} / \mathrm{h}$. The results from the iSed Alcor Auto-instrument were compared to those of Berkhun SDM60 Auto-instrument.

\section{Statistical Analyses}

The calculations were performed by using MedCalc statistical software (ver. 12.3.0.0.; Belgium) and SPSS 17.0 for Windows software (Chicago, IL, USA). The mean and standard deviation (SD) of results derived from both methods were determined. Spearmen's rank correlation analysis test was utilized for correlation analysis. $p<0.05$ is considered significant. Linear regression analysis was performed by Passing-Bablok. Bland-Altman analysis was used to determine bias and limits of agreement [15].

\section{RESULTS}

The mean \pm SD ESR was $24.48 \pm 23.10 \mathrm{~mm} / \mathrm{h}(95 \%$ $\mathrm{Cl}$ for the mean was $20.54-28.02 \mathrm{~mm} / \mathrm{h}$ ) for iSed Alcor Auto-instrument and $23.94 \pm 17.24 \mathrm{~mm} / \mathrm{h}(95 \%$ $\mathrm{Cl}$ for the mean was $21.15-26.73 \mathrm{~mm} / \mathrm{h}$ ) for the Berkhun Auto-instrument. We found the mean difference between two methods as $0.336 \mathrm{~mm} / \mathrm{h}(95 \%$ $\mathrm{Cl}$ for the mean was -2.06 to $1.39 \mathrm{~mm} / \mathrm{h} ; \mathrm{p}=0.701$ ) (Table 1). The obtained correlation coefficient was $0.90(P=0.0001)$.

Table 1. The mean and standard deviation (SD) values of erythrocyte sedimentation rate (SER) from the iSed Alcor Auto-instrument and Berkhun SDM60 Auto-instrument. ESR results are presented in $\mathrm{mm} / \mathrm{h}$.

\begin{tabular}{lccc}
\hline & $\begin{array}{c}\text { Number of } \\
\text { patients }(\mathrm{n})\end{array}$ & $\begin{array}{c}\text { Mean } \pm \text { standard } \\
\text { deviation }\end{array}$ & $\mathrm{p}$ \\
\hline $\begin{array}{l}\text { iSed Alcor } \\
\text { Auto-instrument }\end{array}$ & 149 & $24.48 \pm 23.10$ & $0.701^{*}$ \\
$\begin{array}{l}\text { Berkhun SDM60 } \\
\text { Auto-instrument }\end{array}$ & 149 & $23.94 \pm 17.24$ & \\
\hline
\end{tabular}

*Derived by comparing the results of iSed Alcor Auto-instrument and Berkhun SDM60 Auto-instrument. 
Passing-Bablok regression analysis yielded the equation " $y=-4.90+1.18 x$ " between the two methods. The iSed Alcor method $(n=149)$ yielded a slope of $1.18(95 \% \mathrm{Cl}, 1.08-1.29)$ with an intercept of $-4.90(95 \% \mathrm{Cl},-6.82$ to 2.72$)$ (Figure 1$)$.

The agreement between the results from these two methods is presented in different plots according to Bland-Altman. There was no evidence of systemic bias, equal to $0.3 \mathrm{~mm} / \mathrm{h}$ (limits of agreement, -20.6 to $21.2 \mathrm{~mm} / \mathrm{hr}$ ) (Figure 2).

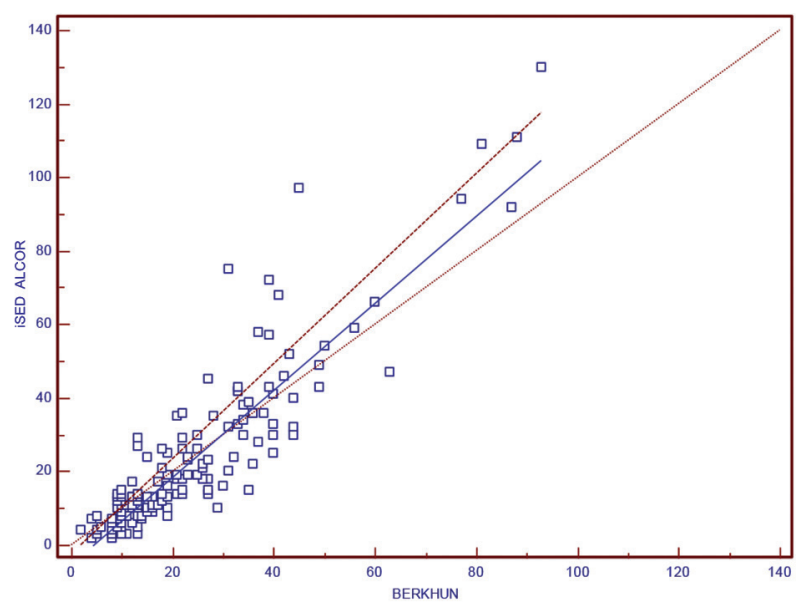

Figure 1. The regression analysis of ESR results from the iSed Alcor Auto-instrument and Berkhun SDM60 Auto-instrument

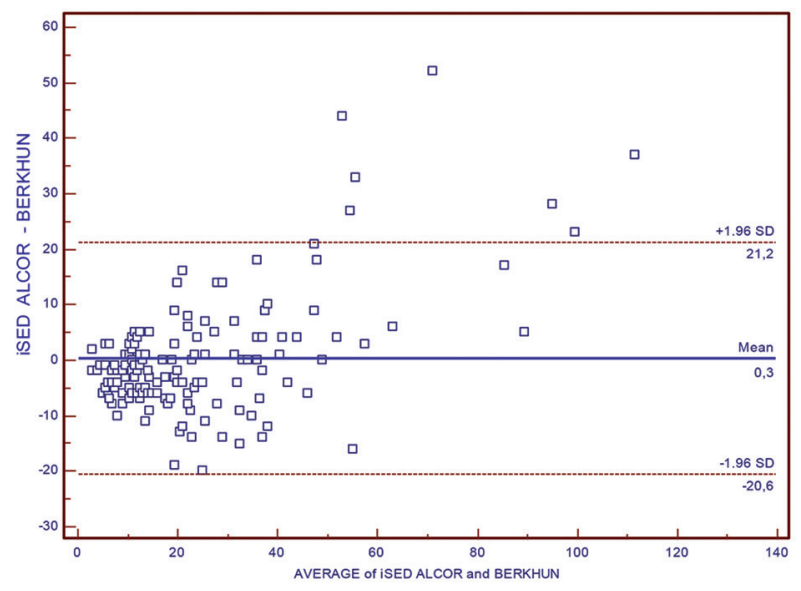

Figure 2. The Bland Altman plot of differences in ESR values from the iSed Alcor Auto-instrument and Berkhun SDM60 Auto-instrument for the ESR mean of 149 patients.

\section{DISCUSSION}

ESR physiologically increases with age. Females and those with hypercholesterolemia have a higher
ESR than males and those without hypercholesterolemia $[16,17]$. A higher ESR is a diagnosis criterion for polymyalgia rheumatica and temporal arteritis [18-20]. If patients with unexplained symptoms or impaired condition are suggestive of inflammatory, neoplastic or infectious disease and the physical examination are not helpful, the ESR should be considered in examination $[1,3]$.

Westergren is a reference method for ESR measurement and used to validate other tests used in ESR measurement. Alternative methods are needed because the Westergren method was affected by the room temperature, delivers the results in a long period of time, has a high risk of infection, vulnerable to environmental contamination, and needs citrated plasma. On the other hand, first semi-automated systems and then full-automated systems were emerged. Recent methods allowed to use blood containing EDTA instead of citrated whole blood and measure both hematologic parameters and the ESR in the same tube and the same time. However, studies are currently being performed as to what anticoagulant should be used to obtain the optimum results in ESR measurement $[8,13,21,22]$. Using citrated whole blood in the method to measure ESR means that the blood must be collected into separate tubes for hemogram and ESR. But collecting blood into tubes with EDTA means that the same tube will be used for both hemogram and ESR measurement. There are various ESR measuring instruments developed for this purpose and iSed Alcor Auto-instrument used in our study measures the ESR in tubes with EDTA. In our study, iSed Alcor Auto-instrument and Berkhun SDM60 Autoinstrument that measure using new methods were compared. iSed Alcor Auto-instrument uses the whole blood with EDTA whereas Berkhun SDM60 Auto-instrument uses the citrated whole blood.

There are numerous studies in the literature that compare the systems used in measuring method of ESR. Alifax TEST 1 system, one of the automated systems, measures the ESR using undiluted EDTA samples or diluted citrate samples. The ESR results from the Alifax TEST 1 system have a good correlation to Westergren method [23]. Hardeman et al compared the StaRRsed Auto-Compact to the Alifax TEST 1 in their study and found good correlation. However, different treatment protocols were administered to $11.5 \%$ of patients based on the system used [24].

Cerutti et al compared the Ves Matic Cube 80 instrument to the Westergren method in their study and identified that systematic bias was 1.2 and limit 
of agreement ranged from 17.4 to 19.9 [25]. In a study by Sezer et al, Ves Matic Cube 200 instrument was compared with Bland-Altman analysis method using Westergren method and found systematic bias being 0.7 and limits of agreement ranging from 32.6 to 31.2. The correlation coefficient was 0.82 in the same study [8]. In another study, the SEDIsystem and the StaRRsed system using citrated whole blood were compared to the Ves-Matic Cube 200 system and Westergren method using whole blood with EDTA. A significant negative bias was identified in the results from the Ves-Matic Cube 200 system after performing the Bland-Altman analysis, and the results were lower by $32 \%$. This negative bias is more apparent particularly in lower results. The Pearson correlation coefficient was low $(r=0.83)$ in the results of Ves-Matic Cube 200 system with Westergren method. The correlation ( $r$ ) of ESR results from the SEDIsystem and the StaRRsed system with Westergren method was 0.96 in both. Hematocrit levels were low in many samples, which were measured $20 \%$ higher in the Ves-Matic Cube 200 system whereas the hematocrit levels were high in those that were measured $20 \%$ less when compared to the Westergren method. These results indicate that measurement of the Ves-Matic Cube 200 system using tubes with EDTA were affected by the hematocrit levels and this difference may be reduced by considering hematocrit levels. This study also demonstrates that the Ves-Matic Cube 200 system is not an alternative to the Westergrenbased method, or vice versa, and the same method must be used to measure in follow-up of patient outcomes [1]. Since whole blood sample is diluted in Westergren-based methods, both plasma proteins and RBC are diluted and the ESR is increased [26]. AlFadhli et al compared the ESR measurements of automated SEDIsystem by Westergren method in their study. They identified a very strong correlation between these two methods using Pearson regression analysis. However, a problem of agreement existed between two methods when used Bland and Altman statistical method. In the same study, ESR values from the automated SEDIsystem had a negative bias. Individuals with high ESR $(>50 \mathrm{~mm} /$ $\mathrm{hr}$ ) had low values measured by the automated SEDIsystem whereas individuals with normal ESR had no different values. It was explained that a correction factor would be useful to use in ESR calculation if the results were to present with the automated SEDIsystem [13]. In another study compared the StaRRsed analyzer to the Westergren method. The difference in the mean values from both of the meth- ods was $16.2 \%$ and the correlation coefficient derived from the Passing-Pablok analysis method was 0.72 . There was a non-linear relationship between the methods. In the StaRRsed analyzer method, the blood is first collected into tube with EDTA and then into the citrated tube. Thus, it is the main difference compared to the classical method in this way. The two different anticoagulants used in the StaRRsed analyzer method might be the primary reason for variance in the results [14]. We did not identify any differences in the ESR results from the iSed Alcor Auto-instrument and Berkhun SDM60 Auto-instrument systems and there was a good correlation between the two systems $(r=0.90)$. Also, no systemic bias was present between the two systems.

In conclusion, iSed Alcor Auto-instrument might be used as an alternative to the Berkhun SDM60 Auto-instrument, or vice versa. However, it should be monitored carefully, especially in high ESR values and the results should be checked according to the Westergren method. This study needs to be confirmed with the Westergren method, which is the golden Standard, because of bias in high ESR levels.

\section{REFERENCES}

1. Curvers J, Kooren J, Laan M, et al. Evaluation of the Ves-Matic Cube 200 erythrocyte sedimentation method: comparison with Westergren-based methods. Am J Clin Pathol 2010;134:653-660.

2. Tinetti ME, Schmidt A, Baum J. Use of the erythrocyte sedimentation rate in chronically ill, elderly patients with a decline in health status. Am J Med 1986;80:844848.

3. Erikssen G, Liestol K, Bjornholt JV, et al. Erythrocyte sedimentation rate: a possible marker of atherosclerosis and a strong predictor of coronary heart disease mortality. Eur Heart J 2000;21:1614-1620.

4. Toklu GD, Akağaç AE, Ağca H. Brusellozda spesifik olmayan laboratuvar testlerinin tanıdaki önemi. J Clin Exp Invest 2012;3:87-90.

5. Bottiger LE, Svedberg CA. Normal erythrocyte sedimentation rate and age. Br Med J 1967; 2:85-87.

6. Brigden ML. Clinical utility of the erythrocyte sedimentation rate. Am Fam Physician 1999;60:1443-1450.

7. Miller A, Green M, Robinson D. Simple rule for calculating normal erythrocyte sedimentation rate. Br Med J (Clin Res Ed) 1983;286:266.

8. Sezer S, Yilmaz FM, Kaya O, et al. Evaluation of VesMatic Cube 200 for erythrocyte sedimentation rate determination. J Clin Lab Anal 2013;27:367-372.

9. Westergren $A$. The technique of the red cell sedimentation reaction. Am Rev Tuberc 1926;14:94-100. 
10. Westergren A. Studies of the suspension stability of the blood in pulmonary tuberculosis. Acta Med Scand 1921;54:247-282.

11. Koçar İH, Erikçi S, Ünübol ME. Eritrosit sedimentasyon hizi ve klinik değeri. Turkiye Klinikleri J Med Sci 1989;9:174-181.

12. Akalin N, Arikan S, Turkeli N, et al. The comparison of different automation systems with reference method for erytrocyte sedimentation rate measurement. Türk Klinik Biyokimya Derg 2004;2:77-82.

13. AlFadhli SM, Al-Awadhi AM. Comparison of erythrocyte sedimentation rate measurement by the automated SEDIsystem and conventional Westergren method using the Bland and Altman statistical method. Med Princ Pract 2005;14:241-244.

14. Horsti J, Rontu R, Collings A. A Comparison Between the StaRRsed Auto-Compact Erythrocyte Sedimentation Rate Instrument and the Westergren Method. J Clin Med Res 2010;2:261-265.

15. Bland JM, Altman DG. Statistical methods for assessing agreement between two methods of clinical measurement. Lancet 1986;1:307-310.

16. Choi JW, Pai SH. Influences of hypercholesterolemia on red cell indices and erythrocyte sedimentation rate in elderly persons. Clin Chim Acta 2004;341:117-121.

17. Miao G. Reference values of erythrocyte sedimentation rate of adult healthy subjects. Arch Med Res 2002;33:506-509.

18. Aletaha D, Neogi T, Silman AJ, et al. 2010 Rheumatoid arthritis classification criteria: an American College of Rheumatology/European League Against Rheumatism collaborative initiative. Arthritis Rheum 2010;62:2569-2581.
19. Cantini F, Salvarani C, Olivieri I, et al. Erythrocyte sedimentation rate and C-reactive protein in the evaluation of disease activity and severity in polymyalgia rheumatica: a prospective follow-up study. Semin Arthritis Rheum 2000;30:17-24.

20. Hazleman B. Laboratory investigations useful in the evaluation of polymyalgia rheumatica (PMR) and giant cell arteritis (GCA). Clin Exp Rheumatol 2000;18:S2931.

21. Imafuku $Y$, Yoshida H, Greenfield S, et al. Automated measurement of erythrocyte sedimentation rate and its relation to red blood cell concentration and plasma proteins. Hematol Cell Ther 1998;40:27-32.

22. de Jonge N, Sewkaransing I, Slinger J, et al. Erythrocyte sedimentation rate by the test- 1 analyzer. Clin Chem 2000;46:881-882

23. Plebani M, De Toni S, Sanzari MC, et al. The TEST 1 automated system: a new method for measuring the erythrocyte sedimentation rate. Am J Clin Patho 1998;110:334-340.

24. Hardeman MR, Levitus M, Pelliccia A, et al. Test 1 analyser for determination of ESR. 1. Practical evaluation and comparison with the Westergren technique. Scand J Clin Lab Invest 2010;70:21-25.

25. Cerutti H, Muzzi C, Leoncini R, et al. Erythrocyte sedimentation rate measurement by VES Matic Cube 80 in relation to inflammation plasma proteins. J Clin Lab Anal 2011;25:198-202.

26. Hardeman MR, Levitus M, Pelliccia A, et al. Test 1 analyser for determination of ESR. 2. Experimental evaluation and comparison with RBC aggregometry. Scand J Clin Lab Invest 2010;70:26-32. 